\title{
PENCEGAHAN PENYEBARAN COVID-19 MELALUI PEMBUATAN DAN PEMBAGIAN HANDSANITIZER BERBAHAN BAKU ALAMI DI KOTA MATARAM
}

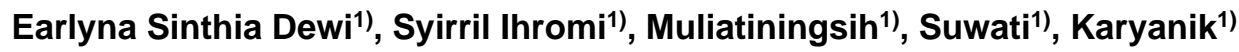 \\ ${ }^{1)}$ Fakultas Pertanian, Universitas Muhammadiyah Mataram, Mataram, Nusa Tenggara Barat, Indonesia \\ Corresponding author : Earlyna Sinthia Dewi \\ E-mail : earlyna.rayes@gmail.com
}

Diterima 11 Mei 2021, Direvisi 10 Agustus 2021, Disetujui 10 Agustus 2021

\begin{abstract}
ABSTRAK
Penyebaran COVID-19 telah menyita perhatian masyarakat dunia termasuk di Indonesia. Covid-19 merupakan penyakit infeksi pernafasan yang dapat ditularkan melalui percikan batuk dan bersin. Tujuan Kegiatan Pengabdian Kepada Masyarakat ini adalah Untuk mengedukasi masyarakat tentang pentingnya menggunakan handsanitizer, dan memberikan pengetahuan bahwa hand sanitizer dapat dibuat menggunakan bahan alami yang ada di lingkungan sekitar. Kegiatan pengabdian ini dilaksanakan di Kelurahan Taman Seruni, Kelurahan Taman Sari,Kecamatan Ampenan,Kota Mataram. Metode pengabdian ada dua tahap yaitu sosialisasi tentang pentingnya penggunaan handsanitizer, diiringi dengan pelatihan pembuatan handsanitizer secara mandiri, dan pembagian handsanitizer kepada warga. Hasil yang diperoleh yaitu 100 warga paham pentingnya penggunaan mendapatkan handsanitizer, selain itu warga mendapatkan handsanitizer dari proses pelatihan. Dengan demikian, masyarakat sekitar pada akhirnya dapat menggunakan handsanitizer pada saat keluar rumah.
\end{abstract}

Kata kunci: covid-19; handsanitizer, bahan alami.

\begin{abstract}
The wide-spread of COVID-19 has confiscates the world community's attention, Indonesia, too. Covid19 is a disease of infected respiration which can be transmitted through coughs and sneezes. The aims of the Community Service Activity are to educate people about the importance of using a hand-sanitizer, and to provide knowledge on that hand sanitizers can be produced by using natural materials in the environments. This service activity was carried out in Taman Seruni, Taman Sari Village, Ampenan subdistrict, Mataram. The method of the community service consists of two stages,the first stage was socialization about how important to using handsanitizer and how to make independently hand-sanitizers as well as distributing hand-sanitizers to people of Taman Seruni. The result was that 100 residents know the importance of using hand sanitizer,beside the residents get a hand-sanitizer from the training process. Thus, they can use hand-sanitizers when they leave the house.
\end{abstract}

Keywords: covid-19; hand-sanitizer; natural materials

\section{PENDAHULUAN}

Corona virus atau yang dikenal dengan covid-19 berasal dari Wuhan di China saat ini telah menyebar ke beberapa benua (Wu et al., 2020).Corona virus merupakan virus yang dapat menyebabkan penyakit pada hewan atau manusia dan mampu menyebabkan infeksi saluran nafas pada manusia mulai dari batuk pilek hingga yang lebih serius seperti Middle East Respiratory Syndrome (MERS) dan Severe Acute Respiratory Syndrome (SARS) (Guan et al., 2020). Pada saat ini laju persebaran Corona virus Disease-2019 (COVID-19) semakin meningkat dan laju penularannya semakin cepat, dapat melalui tetesan air liur bahkan dari cairan pada saat batuk atau bersin, sehingga perlu diupayakan berbagai cara untuk mencegah laju penularan Covid-19.

Menurut badan Kesahatan Dunia (WHO), menganjurkan 12 cara yang dapat dilakukan sebagai upaya pencegahan persebaran Covid19 yang sangat mudah dilakukan secara individu. Salah satu upaya yang sangat dianjurkan untuk mencegah persebaran virus adalah melakukan tindakan sanitasi dengan membersihkan jari jemari atau cuci tangan menggunakan sabun dan cairan hand sanitizer antiseptik (Liu et al., 2010). Kandungan hand sanitizer umumnya adalah alkohol konsentrasi $\pm 60 \%$ sampai $80 \%$. Alkohol memiliki sifat disinfektan yaitu mempunyai aktivitas bakterisidal, yang memiliki efek terhadap berbagai jenis bakteri. Alkohol dapat membantu melarutkan triklosan, berfungsi sebagai 
pemberi rasa dingin di tangan dan agar gel hand sanitizer lebih mudah kering saat digunakan. (Farahim, 2018).

Namun penggunaan hand sanitizer yang mengandung alkohol dan bahan kimia sintetis, dapat menimbulkan masalah pada kesehatan kulit apabila digunakan dalam waktu berkepanjangan (Fatimah \& Ardiani, 2018). Sehingga diperlukan campuran antiseptik berbahan alami yang lebih murah, mudah didapat, dan efektif, salah satunya adalah lidah buaya (Aloe vera).

Penggunaan Lidah buaya (Aloe vera) di beberapa Negara di dunia sebagai obat untuk menyembuhkan penyakit sudah diketahui sejak dulu. Lidah buaya diketahui memiliki aktivitas anti bakteri spektrum luas baik untuk menghambat bakteri gram positif maupun negatif (Heng et al., 2018). Menurut beberapa penelitian yang telah dilakukan, hal ini dikarenakan lidah buaya memiliki kandungan seperti anthraquinone, aloin, aloe-emodin, chromones, aloeresin, pyrocathecol, cinnamic acid, p-coumaric acid, asam askorbat, saponin, glikosida, alkaloid dan tannin yang merupakan kandungan aktif yang berpotensi sebagai antibakteri (Heng et al., 2018).

Berdasarkan latar belakang masalah diatas, maka pengabdi tertarik untuk melakukan melakukan sosialisasi pembuatan hand sanitizer yang diharapkan dapat memberikan pengetahuan dan keterampilan cara pembuatan hand sanitizer gel berbahan alami sekaligus memberikan dampak positif kepada warga mengenai pengetahuan tentang pemanfaatan bahan-bahan alami di lingkungan disekitar Kelurahan Taman Sari

Wilayah Taman Sari Ampenan merupakan salah satu dari 10 Kelurahan di Kecamatan Ampenan, dan merupakan kelurahan pemekaran di Kecamatan Ampenan. Jumlah penduduk Kelurahan Taman Sari adalah sebanyak 8.781 jiwa yang terdiri dari 4.416 jiwa laki-laki dan 4,365 jiwa perempuan, dengan jumlah KK sebesar 2,350 orang, dan terbagi kedalam 30 Rukun Tetangga, dan 6 Lingkungan (BPS,2017). Wilayah Taman Sari juga salah satu wilayah yang sudah terkena zona merah. Banyaknya kasus positif Covid-19 di wilayah Taman Sari membuat masyarakat menjadi panik dan membuat banyak orang mencari beberapa barang yangdiyakini dapat mencegah berbagai virus, seperti hand sanitizer yang merupakan cairan pembunuh kuman. Kini benda tersebut menjadi langka di pasaran. Jika ada pun harganya melambung sangat tinggi dan membuat masyarakat menjadi kesulitan mendapatkannya. Sehingga Melalui kegiatan Pengabdian ini diharapkan dapat memberikan pengetahuan dan keterampilan cara pembuatan hand sanitizer gel berbahan alami sekaligus memberikan dampak positif kepada warga mengenai pengetahuan tentang pemanfaatan bahanbahan alami di lingkungan sekitar.

\section{METODE}

Pengabdian Masyarakat dilakukan pada hari Jum'at tanggal 31 Juli 2020 dengan mitra pada pengabdian ini adalah ibu-ibu rumah tangga yang tergabung dalam kegiatan PKK dan para remaja lingkungan Taman Seruni, Kelurahan Taman Sari, Kecamatan Ampenan yang berjumlah 100 orang. Pelaksanaan pengabdian dilakukan dalam tiga tahapan.

Tahap pertama adalah tahap persiapan yang dilakukan dengan pendekatan penyuluhan personal. Tim membuat Handsanitizer sendiri di Laboratorium Kimia Dasar Fakultas Pertanian Universitas Muhammadiyah Mataram. Adapun Bahan yang diperlukan dalam kegiatan ini antara lain: gel lidah buaya, alkohol 96\%, aquades, carbopol 940, ekstrak jeruk nipis, parfum dan botol kemasan.

Tahap pelaksanaan dilakukan dengan sosialisasi bertahap tentang pentingnya penggunaan handsanitizer, yang dilanjutkan dengan pelatihan pembuatan serta pembagian handsanitizer sejumlah 100 botol isi $100 \mathrm{ml}$ ke warga lingkungan Taman Seruni sesuai dengan protokol covid-19.

Tahap evaluasi dilakukan dengan diskusi pada saat pembagian handsanitizer yang dilakukan secara bertahap untuk mengetahui apakah warga masih mengingat pentingnya penggunaan sanitizer. Tahap evaluasi dilakukan secara bertahap karena tidak boleh berkumpul secara massal sebaya upaya social distancing guna mencegah penyebaran virus covid-19. Pembuatan handsanitizer gel lidah buaya ditunjukkan pada gambar 1 berikut : 


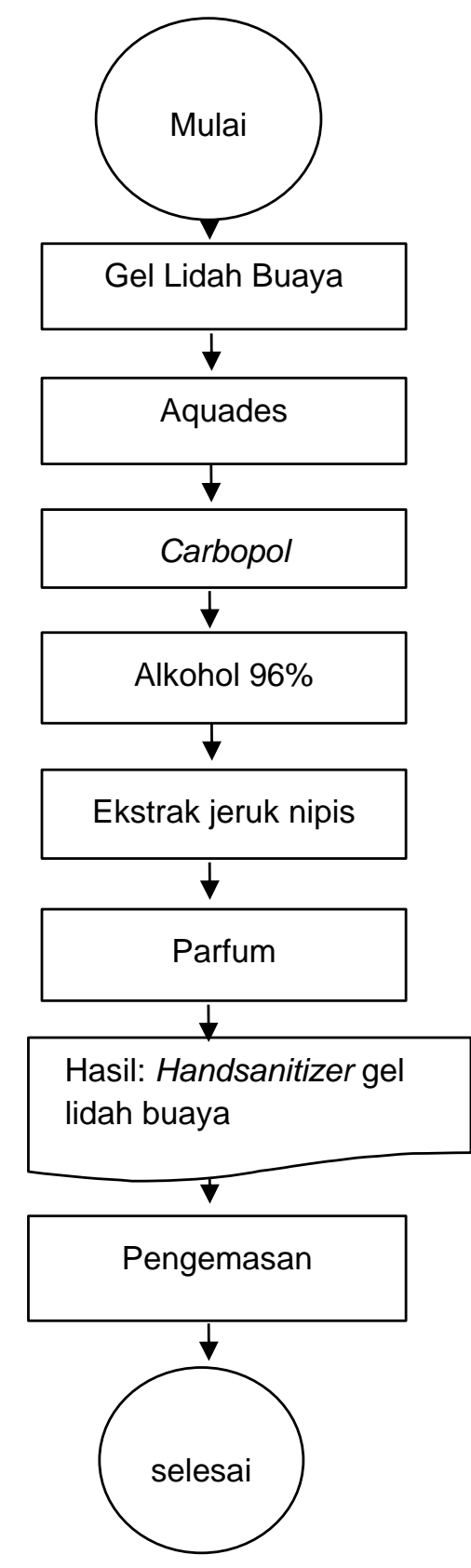

Gambar 1. Diagram Alir Pembuatan Handsanitizer Gel Lidah Buaya

\section{HASIL DAN PEMBAHASAN}

Peserta sangat antusias dalam kegiatan ini, dapat dilihat dari banyaknya warga masyarakat terutama ibu-ibu rumah tangga yang tergabung dalam kegiatan PKK dan para remaja lingkungan Taman Seruni, Kelurahan Taman Sari, Kecamatan Ampenanyang hadir. Kegiatan ini dilakukan dengan tetap mengikuti protokol kesehatan seperti menggunakan masker. Antusias masyarakat juga dapat dilihat dari beberapa pertanyaan yang diajukan oleh masyarakat. Dalam pelaksanaan kegiatan pembagian handsanitizer ini dapat dilakukan beberapa evaluasi sebagai berikut :
1. Penyampaian materi pelatihan mudah dipahami bagi peserta pelatihan karena menggunakan kata-kata yang mudah dipahami dan penambahan beberapa gambar yang membantu dalam menjelaskan materi tersebut . 2. Komunikasi dalam pelatihan cukup baik yaitu adanya tanya jawab antara peserta dan pembicara. Namun hanya beberapa saja peserta yang bertanya .

3. Alat- alat yang digunakan dalam pelatihan mudah untuk diperoleh dan harganya murah seperti mangkuk, sendok, botol spray yang ada di rumah, alkohol $70 \%$ yang dapat ditemukan di apotek terdekat, dan aloe vera gel. 4. Suasana dalam kegiatan pelatihan cukup kondusif, sehingga tidak mengganggu pelaksanaan pelatihan ini

5. Isi materi dalam kegiatan lengkap yaitu terdiri dari informasi pengenalan handsanitizer, alat dan bahan yang digunakan, cara pembuatan, cara memakai, dan informasi lain mengenai manfaat dari aloe vera dalam pembuatan handsanitizer

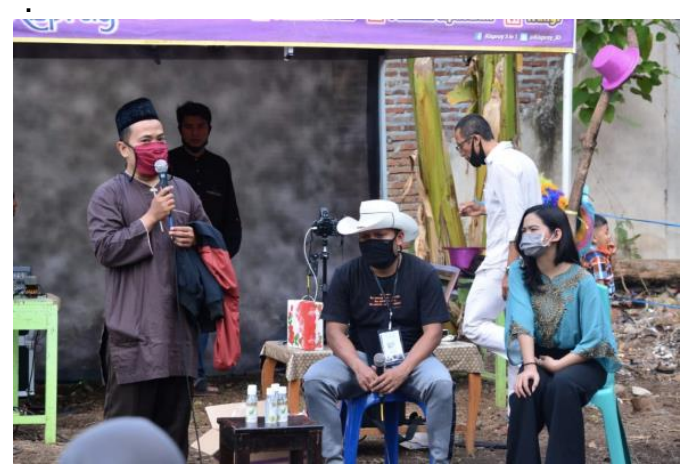

Gambar 2. Penyampaian Materi cara

Pembuatan Handsanitizer Gel Lidah Buaya

\section{SIMPULAN DAN SARAN}

Adanya pelatihan pembuatan hand sanitizer menggunakan lidah buaya atau aloe vera kepada ibu-ibu rumah tangga yang tergabung dalam kegiatan PKK dan para remaja lingkungan Taman Seruni, Kelurahan Taman Sari, Kecamatan Ampenan menjadi salah satu kegiatan yang sangat bermanfaat. Antusiasme dari mereka dalam mendengarkan materi pun cukup baik. Hal ini ditunjukkan dengan adanya beberapa pertanyaan dari peserta dan juga jumlah peserta yang mengikuti acara tersebut cukup memenuhi syarat untuk pelatihan secara langsung atau kontak fisik dengan tetap mematuhi protokol kesehatan seperti menggunakan masker saat kegiatan ini berlangsung. Keterampilan dalam pembuatan hand sanitizer tersebut dapat dimanfaatkan untuk memenuhi kebutuhan pribadi mereka maupun orang lain dengan cara mengajarkan kembali tata cara pembuatan handsanitizer tersebut. Hasil akhir dari kegiatan ini warga 
yang awalnya tidak mengerti tentang pentingnya penggunaan sanitizer, menjadi paham tentang pentingnya penggunaan handsanitizer, hampir lebih dari $80 \%$ warga yang hadir dalam kegiatan sosialisasi mampu menjawab pentingnya penggunaan handsanitizer dan memiliki rasa percaya diri untuk membuat handsanitizer sendiri.

\section{UCAPAN TERIMAKASIH}

Terimakasih kepada bu-ibu rumah tangga yang tergabung dalam kegiatan PKK dan para remaja lingkungan Taman Seruni, Kelurahan Taman Sari, Kecamatan Ampenan yang sudah memfasilitasi berlangsungnya kegiatan pengabdian.

\section{DAFTAR RUJUKAN}

Farahim, A. N. (2018). Pemanfaatan Daun Salam Sebagai Bahan Pembuatan Hand Sanitizer Dalam Bentuk Gel Dengan Penambahan Alkohol Dan Triklosan. Program Studi Pendidikan Biologi Fakultas Keguruan Dan IImu Pendidikan Universitas Muhammadiyah Surakarta, 4, $1-13$.

Fatimah, C., \& Ardiani, R. (2018). Pembuatan Hand Sanitizer ( Pembersih Tangan Tanpa Air ) Menggunakan Antiseptik Bahan Alami. Prosiding Seminar Nasional Hasil Pengabdian, 336-343.

Guan, W., Ni, Z., Hu, Y., Liang, W., Ou, C., He, J., Liu, L., Shan, H., Lei, C., Hui, D. S. C., Du, B., Li, L., Zeng, G., Yuen, K.-Y., Chen, R., Tang, C., Wang, T., Chen, P., Xiang, J., ... Zhong, N. (2020). Clinical Characteristics Of Coronavirus Disease 2019 In China. New England Journal Of Medicine, 382(18), 1708-1720. Https://Doi.Org/10.1056/Nejmoa2002032

Heng, H. C., Zulfakar, M. H., \& Ng, P. Y. (2018). Pharmaceutical Applications Of Aloe Vera. In Indonesian Journal Of Pharmacy (Vol. 29, Issue 3, Pp. 101-116). Https://Doi.Org/10.14499/Indonesianjphar m29iss3pp101

Liu, P., Yuen, Y., Hsiao, H. M., Jaykus, L. A., \& Moe, C. (2010). Effectiveness Of Liquid Soap And Hand Sanitizer Against Norwalk Virus On Contaminated Hands. Applied And Environmental Microbiology, 76(2), 394-399.

Https://Doi.Org/10.1128/AEM.01729-09

Wu, D., Wu, T., Liu, Q., \& Yang, Z. (2020). International Journal Of Infectious Diseases The SARS-Cov-2 Outbreak: What We Know. Elsevier, 94, 44-48. 